\title{
DEVELOPMENT AND PSYCHOPATHOLOGY
}

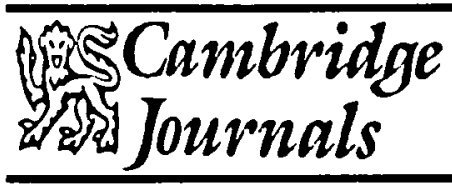

\section{EDITORS:}

Dante Cicchetti, University of Rochester Barry Nurcombe, Child and Adolescent Psychiatric Hospital, Vanderbilt University

This multidisciplinary journal is devoted to the publication of original empirical, theoretical and review papers which address the interrelationship of normal and pathological development in adults and children. It is intended to serve and integrate the emerging field of developmental psychopathology which strives to understand patterns of adaptation and maladaptation throughout the life span. Explorations of abnormal functioning in the social, emotional, cognitive, linguistic and biological domains help to clarify normal developmental processes. Reciprocally, elucidations of principles of normal development help to broaden our understanding of psychopathological conditions. Contributions may also be on the processes underlying the adaptive outcomes in populations "at risk" for psychopathology. This journal is of vital interest to psychologists, psychiatrists, social scientists, neuroscientists, pediatricians and researchers.

Development and Psychopathology (ISSN 09545794) is published quarterly. Subscriptions to Volume 1 (1989) or Volume 2 (1990) are each $\$ 75.00$ for institutions; $\$ 35.00$ for individuals; single parts $\$ 20.00$.

Send orders to: Journals Department Cambridge University Press 40 West 20th Street New York, NY 10011 


\section{BEHAVIORAL and BRAIN SCIENCES}

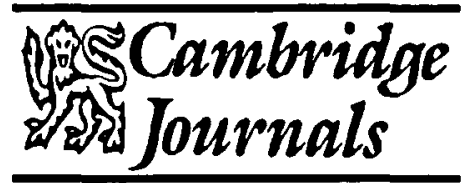

EDITOR:

Stevan Harnad, Princeton, NJ

Behavioral and Brain Sciences publishes particularly significant and controversial "target articles." These have been successful in drawing out the leading investigators in a wide range of fields who discuss, debate and critically analyze topics of current interest to the entire biobehavioral science community. Fascinating and often surprising results come from the 20-30 open peer commentaries on each target article from psychologists, linguists. philosophers, neuroscientists, anthropologists, developmentalists and other specialists within and across these disciplines.

\section{Selected Papers}

Sex differences in human mate preferences: Evolutionary hypothesis tested in 37 cultures, D.M. Buss

A solution to the tag-assignment problem for neural networks, Gary W. Strong, Bruce A. Whitehead

Strategies for the control of voluntary movements with one degree of freedom, G.L. Gottlieb et al.

Numerical competence in animals: Definitional issues, current evidence and a new research agenda, $H$. Davis, $R$. Perusse

Genetic similarity, human altruism, and group intelligence, J. Philippe Rushton

Behavioral and Brain Sciences (ISSN 0140-525X) is published quarterly. Subscription to Volume 131990 (US and Canada only): $\$ 164.00$ for institutions; $\$ 69.00$ for individuals; single parts $\$ 45.00$.

Back Volumes: $1-12$ (1978-1989) $\$ 160.00$ each.

Send orders to:

Journals Department

Cambridge University Press

40 West 20th Street, New York, NY 10011, USA; or

The Edinburgh Building. Cambridge CB2 2RU, UK 
Please enter my subscription to

\section{VISUAL NEUROSCIENCE}

Published Monthly (ISSN 0952-5238)

1990, Vols. 4 and 5,

Two volumes of six issues each.

Annual subscription rates:
口\$280.00 Institutions
$\square \$ 120.00$ Individuals*
ㅁ\$80.00 Students*

*Discounted individual and student rates payable by personal check or credit card only. Students must supply proof of current enrollment.

Please note: If paying by credit card, enclose this card in an envelope for your security.

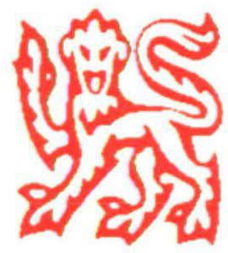

Please enter my subscription to

\section{VISUAL NEUROSCIENCE}

Published Monthly (ISSN 0952-5238)

1990, Vols. 4 and 5,

Two volumes of six issues each.

Annual subscription rates:
$280.00 Institutions
ㅁ $\$ 120.00$ Individuals*
$\$ 80.00$ Students*

-Discounted individual and student rates payable by personal check or credit card only. Students must supply proof of current enrollment.

Please note: If paying by credit card, enclose this card in an envelope for your security.

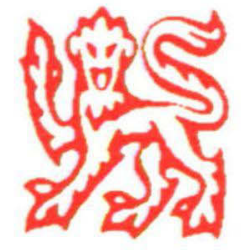

Please enter my subscription to

\section{VISUAL NEUROSCIENCE}

Published Monthly (ISSN 0952-5238)

1990, Vols. 4 and 5 ,

Two volumes of six issues each.

Annual subscription rates:

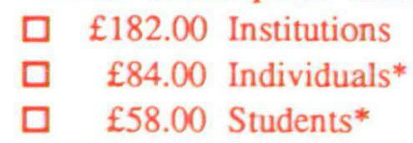

-Discounted individual and student rates payable by personal check or credit card only. Students must supply proof of current enrollment

Please note: If paying by credit card, enclose this card in an envelope for your security.
Name of subscriber

Addres,

\begin{tabular}{lll}
\hline Cify & State/Prov & Zip
\end{tabular}

Payment enclosed. (Payment may be made in U.S. dollars or equivalent in Canadian dollars.)

$\square$ VISA $\square$ MasterCard interbank no.

Card no Expires

Signature

No postage necessary if mailed in the U.S.A.

Cambridge University Press

40 West 20th Street, New York, NY 10011

\begin{tabular}{ll} 
Name of subscriber \\
\hline Address \\
\hline Citv State Prov
\end{tabular}

Payment enclosed. (Payment may be made in U.S. dollars or equivalent in Canadian dollars.)

$\square$ VISA $\square$ MasterCard Interbank no.

Card no. Expires

Signature

No postage necessary if mailed in the U.S.A.

Cambridge University Press

40 West 20th Street, New York, NY 10011

Please send this form to any bookseller or subscruption agent or direct to Cambridge University Press. The Fdinburgh Building Shaftestoury Road. Cambridge CB2 2RU, England

Orders sent to the Press must be accompanied by payment which mav be made. in terling by cheque UK Postal Order. International Money Order hank transter

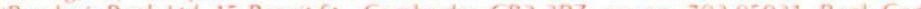

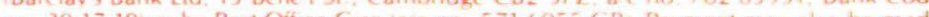

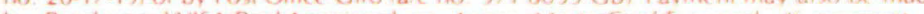

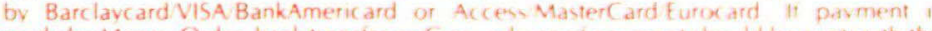
made by Monev Order, bank transter or Gito advice of pavment should be went with the order to the Press. Cheques should be made pavable to Cambridge L niversits. Press

Payment enclosed

Payment by Barclaycard/VISA or Access MasterCard

Eurocard

Signature of cardholder.

Date Amount

Barclavcard/ISA BankAmeric ard number

Access/MasterCard/Eurocard number

Vame of subscriber 


BUSINESS REPLY $\underset{\text { FIRST CLASS }}{\text { MAIL }}$ RIL

POSTAGE WILL BE PAID BY ADDRESSEE

\section{CAMBRIDGE UNIVERSITY PRESS}

Attn: Journals Department

40 West 20th Street

New York, NY 10114-0495

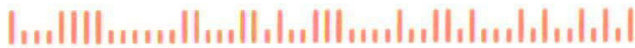

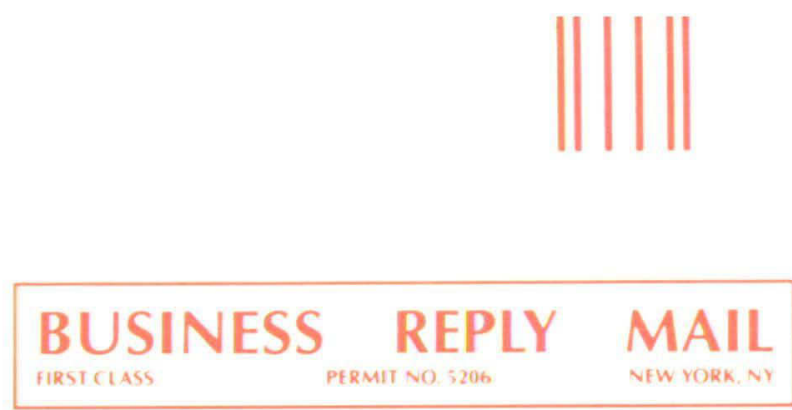

POSTAGE WILL BE PAID BY ADDRESSFE

\section{CAMBRIDGE UNIVERSITY PRESS}

Attn: Journals Department

40 West 20th Street

New York, NY 10114-0495

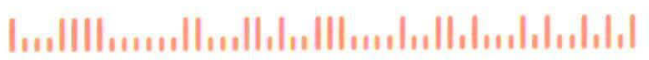

\section{CAMBRIDGE UNIVERSITY PRESS}

The Edinburgh Building

Shattesbury Road

Cambridge CB2 2RL

England 


\section{PSYCHOLOGICAL SCIENCE}

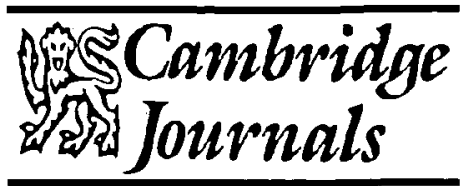

Published for the

American Psychological Society

\section{EDITOR}

William K Estes, Harvard University

Psychological Science is a new bimonthly publication being launched as the flagship joumal of the American Psychological Society, founded 1988 , to regain the scientific focus of psychological research. The journal is designed to be the forum for research, theory, and application in psychology and the closely related behavioral, cognitive, neural, and social sciences. The journal also considers psychology in government and public affairs. Unlike most research journals, Psychological Science encourages articles of general theoretical significance or of broad interest across specialties.

\section{Recent Articles}

The Prenatal Origins of Behavioral Organization, William $P$ Smotherman and Scott $R$ Robinson

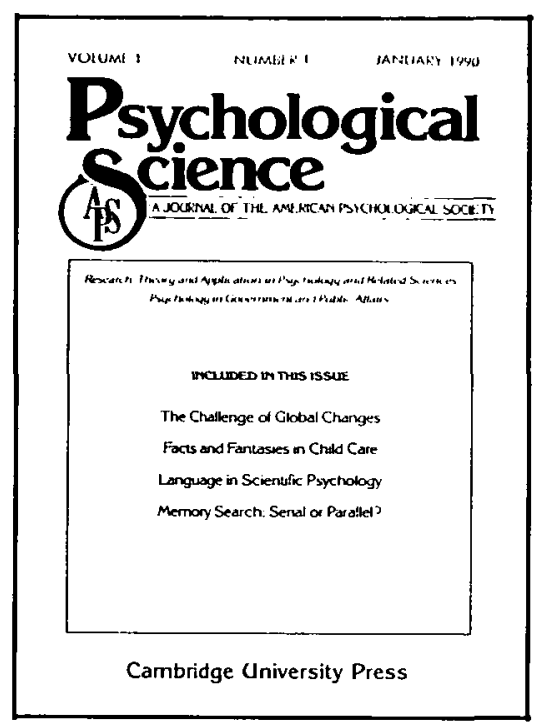

Facts, Fantasies, and the Future of Child Care in the United States, Sandra Scarr et al.

Serial vs Parallel Processing, James T Townsend

Answering Reading Comprehension Items Without Passages on the SAT, Stuart Katz et al.

Infants' Perception of Phase Structure in Music, Carol L Krumhansl and Peter W Jusczyk

Psychological Science (ISSN 0956-7976) is published bimonthly. Volume 1 (1990) subscriptions (US and Canada only): $\$ 100.00$ institutions; $\$ 50.00$ for nonmember individuals. APS members receive the journal as part of their dues.

Send order to:

Journals Department

Cambridge University Press

40 West 20th Street, New York, NY 10011, USA; or

The Edinburgh Building, Shaftesbury Road, Cambridge CB2 2RU, UK 


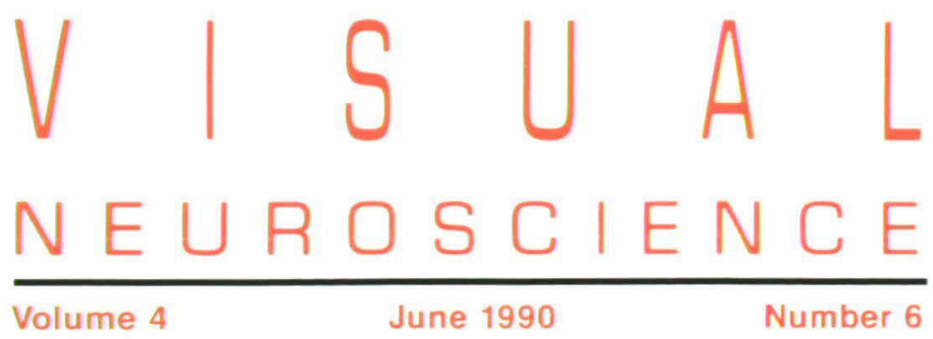

\section{CONTENTS}

\section{Research Articles}

Thomas E. Hughes

Thomas E. Hughes

BERND FRITZSCH AND Shaun P. Collin

JEANine NGUYen-LEgRos, FATIMA Moussafi AND Axelle Simon

Anne Morel AND JEAN BULliER

R.B. PINTER, D. OSORIO AND M.V. SRINIVASAN

Helen Mcintosh, Nigel Daw AND DAVID PARKINSON

Grant W. BalKema AND Ursula C. Dräger

K.L. Grasse, M. ARIEL AND I.D. SMITH

JAN M. PROVIS AND John Mitrofanis DAVID FERSTER
A light- and electron-microscopic investigation of the optic tectum of the frog, Rana pipiens, I: The retinal axons

A light- and electron-microscopic investigation of the optic tectum of the frog, Rana pipiens, II: The neurons that give rise to the crossed tecto-bulbar pathway

Dendritic distribution of two populations of ganglion cells and the retinopetal fibers in the retina of the silver lamprey (Ichthyomyzon unicuspis)

Sclerally directed processes of dopaminergic interplexiform cells reach the outer nuclear layer in rat and monkey retina

Anatomical segregation of two cortical visual pathways in the macaque monkey

Shift of edge-taxis to scototaxis depends on mean luminance and is predicted by a matched filter theory on the responses of fly lamina LMC cells

GAP-43 in the cat visual cortex during postnatal development

Origins of uncrossed retinofugal projections in normal and hypopigmented mice

Direction-selective responses of units in the dorsal terminal nucleus of cat following intravitreal injections of bicuculline

\section{Short Communication}

NADPH-diaphorase neurones of human retinae have a uniform topographical distribution

Binocular convergence of excitatory and inhibitory synaptic pathways onto neurons of cat visual cortex

1 Acknowledgment to Ad Hoc Reviewers

Detailed Information for Contributors

The Humane Care and Use of Animals

Author Index and Contents to Volume 4 